


\title{
REDEFINISI HUKUM ISLAM DALAM KERANGKA DEMOKRASI Eksperimentasi Muḥammad Shaḥrūr
}

\author{
Muhyar Fanani \\ IAIN Walisongo Semarang \\ e-mail: muhyarfa@yahoo.co.id
}

\begin{abstract}
This article discusses the new paradigm of Islamic law which is offered by Muhammad Shahrūr, one of the contemporary Muslim thinkers from Suria. The focus of study on this paper is an attempt to criticize the redefinition of the basic concepts of Islamic law in Shahrūr view. According to Shahrūr, redefinition basic concepts in Islamic law must be done as a starting point to develop a new paradigm of Islamic law which is based on anthropocentric approaches, - not theocentric approaches. Islamic law is civil law, democratic and positive. Therefore, it requires more realistic, elastic, and implementable definition. For Shahrūr, the existence of a new paradigm, such as the democratization of Islamic law is very urgent in the midest of the Muslim world today on the era of the nation state, constitutionalism and democracy, rapidly changing, and increasingly distant from the tyranny period.
\end{abstract}

[]

Artikel ini mendiskusikan paradigma baru dari hukum Islam yang ditawarkan oleh Muhammad Shahrūr, salah seorang dari pemikir Muslim kontemporer dari Syiria. Fokus kajian dalam tulisan ini adalah mengkritisi upaya redefinisi terhadap konsep-konsep dasar Hukum Islam oleh Shahrūr. Menurut Shahrūr redefinsi konsep-konsep dasar dalam Hukum Islam harus dilakukan sebagai starting point dalam membangun paradigma baru hukum Islam yang lebih berbasis antroposentris, - bukan teosentris. Hukum Islam adalah hukum sipil, demokratis dan positif. Oleh karenanya sangat membutuhkan definisi-definisi yang lebih realistis, elastis, dan implementatif. Bagi Shahrūr, eksistensi paradigma baru, yaitu demokratisasi Hukum Islam ini terasa sangat urgen di tengah kondisi dunia Muslim saat ini yang berada pada era negara bangsa, konstitusionalisme dan demokrasi, cepat berubah, dan semakin jauh dari masa tirani sama sekali.

Keywords: hukum Islam, paradigma baru, uṣūl al-fiqh, hudūd

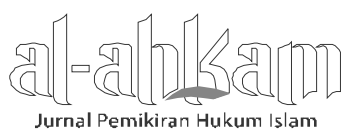




\section{Pendahuluan}

"Kita harus membangun ușūl yang kontemporer dan baru, jika kita ingin menghasilkan fikih Islam yang baru..." ${ }^{11}$ Kutipan di atas, walaupun sudah pernah dikumandangkan oleh Hasan al-Turābī, ${ }^{2}$ Yusuf al-Qarḍāwīỉ dan al-Jābirī, namun memiliki bobot yang jauh lebih tinggi ketika diucapkan oleh Shahrūr. Mengapa? Karena Shahrūr tidak hanya merasa cukup dengan mengatakan atau mengajak para ilmuwan keislaman akan pentingnya rancang bangun ilmu usul fikih yang baru, tapi ia melakukan sendiri apa yang ia serukan itu. Ia melakukan penelitian yang tanpa henti untuk mewujudkan usul fikih yang baru. Inilah yang tidak dilakukan oleh intelektual lain dalam bidang usul fikih, termasuk Hasan al-Turābī, Yusuf al-Qarḍāwī dan al-Jābirī. Bagaimanakah rancang-bangun baru ilmu usul fikih yang dibuat oleh Shahrūr, atau dengan kata lain, bagaimanakah struktur kemasukakalan (plausibility structure) Shahrūr - meminjam istilah Peter L. Berger-dalam ilmu usul fikih, itulah yang akan dibicarakan dalam tulisan ini. Untuk memperdalam kajian, tentu saja tidak semua aspek akan dibicarakan, tapi hanya aspek hukum saja.

Mengingat pemikiran Shahrūr memiliki tingkat kerumitan yang tinggi, maka pembaca dipersilahkan juga menelaah publikasi lain yang dilakukan penulis tentang Shahrūr. ${ }^{5}$ Disamping itu, karena Shahrūr sering memberikan definisi baru atas istilah-istilah yang selama ini telah memiliki makna populer, untuk mempermudah pemahaman tulisan ini, maka penulis mencetak miring (italic) dan tebal (bold) istilah-istilah yang dalam tulisan ini dimaksudkan tidak mengacu pada

${ }^{1}$ Muhammad Shahrūr, Naḥw Ușūl Jadīdah li 1-Fịh al-Islāmī (Damaskus: al-Ahāīi li 'th-Thibā'ah li 'n-Nashr wa at-Tawzī', 2000), h. 189.

${ }^{2}$ Hasan al-Turābī, Pembaharuan Ushul Fiqh, h. 1-33; Hasan al-Turābī, Fiqh Demokratis: Dari Tradisionalisme Kolektif Menuju Modernisme Populis, terj. Abdul Haris dan Zaimul Am (Bandung: Penerbit Arasy, 2003), h. 50-67.

3Yūsuf al-Qarḍāwī, Fatwa-fatwa Kontemporer, terj. As'ad Yasin (Jakarta: Gema Insani Press, 1995), h. 211-213.

4al-Jābirī, Agama, Negara, dan Penerapan Syari'ah, terj. Mujiburrahman (Yogyakarta: Fajar Pustaka Baru, 2001), h. 148-149.

5Lihat: Muhyar Fanani, "Muhammad Shahrūr dan Konsepsi Baru Sunah", dalam Jurnal Teologia vol. 15, nomor 2, Juli 2004, h. 143-169; Muhyar Fanani, "Bagaimana Mendefinisikan Ulang Sumber Hukum Islam? Sebuah Tawaran Muhammad Shahrūr ", dalam International Journal Ihya' 'Ulum alDin Volume 9. Number 1, June 2007, h. 1-26. 
makna populer tapi mengacu pada makna baru yang diberikan Shaḥrūr, seperti istilah hanīf, ${ }^{6}$ hudūdī, ${ }^{7}$ nubuwwah ${ }^{8}$ dan risālah. ${ }^{9}$

\section{Islam sebagai Agama Internasional dan Universal}

Ajaran Islam harmonis dengan fitrah manusia dan hukum alam. Oleh karena itu Allah mengaitkan firman-Nya: “... (tetaplah atas) fitrah Allah yang telah menciptakan manusia menurut fitrah itu.” (QS. al-Rūm: 30), —yakni keserupaan tabiattabiat manusia dengan hukum alam — dengan firman-Nya: “...tidak ada perubahan pada fitrah Allah.” Kemudian Allah mengaitkan pada akhir ayat bahwa agama ini adalah "agama yang lurus". Artinya: pemegang kekuasaan dan kekuatan yang akhirnya memiliki sifat keabadian (al-qayyūmiyyah). Allah juga menegaskan bahwa mayoritas manusia tidak mengetahui hakikat Islam ini bahwasanya Islam adalah agama yang harmonis dengan karakter fitrah dan hukum alam secara bersamaan. Di sinilah, menurut Shahrūr, tersembunyi krisis fikih Islam. ${ }^{10}$

Dalam pandangan Shahrūr, krisis fikih harus diselesaikan dengan berangkat dari rekonstruksi usul fikih, bukan rekonstruksi fikih. Rekonstruksi usul fikih akan menjadi dasar pijak semua bentuk penafsiran dan ijtihad hukum. ${ }^{11}$ Sementara rekonstruksi fikih tanpa didahului dengan rekonstruksi usul fikih akan menjadi langkah yang absurd. Seseorang tidak mungkin membangun rumah baru yang berbasis pada teknologi beton bertulang, sementara mindset-nya hanya mengenal teknologi rumah berbasis ilalang. Seseorang yang hanya mengerti alam pikir

6Dalam kamus, hanīf memiliki dua arti yakni māla (miring, condong) dan istaqāma (lurus). Shahrūr memilih arti yang pertama, sementara kebanyakan para ahli memilih arti yang kedua. Oleh karena itu, dalam terminologi Shahrūr, agama yang hanīf adalah agama yang mengandung kelenturan dan fleksibelitas bukan agama yang rigid (kaku).

${ }^{7}$ Dalam terminologi Shahrūr, ḥudūdī, berarti sebuah paradigma hukum yang meyakini bahwa hukum yang tertera dalam wahyu itu adalah hukum yang bersifat batasan (limitatif). Dengan demikian, manusia dipersilahkan untuk berijtihad menciptakan hukumnya sendiri asal tidak menyalahi batasan itu.

8Dalam terminologi Shahrūr, nubuwwah berarti semua informasi dalam al-Kitāb yang diwahyukan kepada Nabi SAW yang dengannya ia disebut sebagai Nabi. Oleh Shahrūr nubuwwah juga dijadikan nama lain terhadap al-Qur'ān.

'Dalam terminologi Shahrūr, risālah berarti kumpulan tasyri' (ketetapan hukum) yang datang kepada nabi sebagai tambahan terhadap informasi yang dengan tambahan itu ia disebut sebagai rasul.

10Shahrūr, al-Kitāb wa '-Qur'ān, h. 575.

${ }^{11}$ Shahrūr, Naḥw Ușūl Jadīdah..., h. 95.

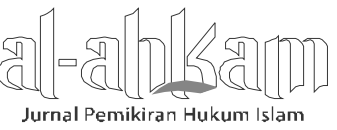


pedusunan, pasti sulit memahami bagaimana orang-orang yang tinggal di apartemen-apartemen bertingkat dan tidak pernah bisa bercocok tanam dapat memperoleh makanan. Rekonstruksi fikih tak mungkin dilakukan tanpa rekonstruksi usul fikih terlebih dahulu.

Dalam pandangan Shahrūr, selain sebagai agama internasional dan universal, Islam juga merupakan agama yang hanīf. Kata hanïf berasal dari kata hanafayahnifu-hanfan yang kemudian menjadi sifat musyabbahah (hanïf). Kata hanif memiliki dua arti sekaligus; yakni māla (miring, condong, doyong) dan istaqāma (lurus). Orang yang beriman secara benar (lurus) atau orang yang memeluk - atau condong pada - agama yang benar disebut ḥanîf. Al-dīn al-hanïf berarti agama yang benar, agama yang lurus. ${ }^{12}$ Walaupun memiliki dua arti, namun arti yang populer dari kata hanif adalah "lurus". ${ }^{13}$ Berangkat dari prinsip anti-sinonimnya, Shahrūr mengartikan kata haniff bukannya "lurus", tapi "kecondongan atau penyimpangan" ("al-mayl wa 'l-inhiriräf').14 Dengan demikian, apabila "lurus" kita anggap sama dengan "statis" dan "condong" sama dengan "lentur", maka agama yang benar, dalam pandangan Shậrūr, bukanlah agama yang statis dan rigid dalam segala ajarannya, tapi agama yang mengandung unsur-unsur kelenturan dan fleksibilitas.

Lebih jauh menurut Shaḥūr, orang yang pertama kali mampu menyingkap konsep hanif dalam sejarah umat manusia adalah Ibrahim. Itulah keistimewaan Ibrahim atas semua nabi dan rasul yang lain. Ibrahim mampu mengungkap fenomena hanīf, "yang berubah", dan ia mampu selamat darinya. Dengan penemuannya

\footnotetext{
${ }^{12}$ Mușțafā al-Ghalayaynī menyatakan bahwa sifat musyabbahah yang terbentuk dari wazan fa'ala seperti ini sangat sedikit dalam bahasa Arab. Kata hanīf adalah satu diantara yang sedikit itu. Lihat: Mușțafā al-Ghalayaynī, Jāmi' ad-Durūs al-'Arabiyyah, juz I (Beirut: Manshūrāt al-Maktabah al'Așriyyah, 1987), h. 185, 190; Ahmad Warson Munawwir, al-Munawwir (ttp.: tnp., t.t.), h. 328; Hans Wehr, A Dictionary of Modern Written Arabic, J. Milton Cowan (ed.), cet. ke-3 (Beirut: Maktabah Lubanan, t.th.), h. 210; al-Shawāf sebagai pengkritik Shahrūr paling keras juga mengakui bahwa kata hanif memang memiliki banyak arti. Orang Arab kadang menggunakannya sebagai al-mayl, tapi kadang menggunakannya sebagai al-istiqāmah. Muhāmī Munīr Muhammad Tāhir Asy-Syawāf, Tahāfut al-Qirā'ah al-Mu'āṣirah, cet. 1 (Cyprus: al-Shawwāf li' l-Nashr wa 'l-Dirāsāt, 1993), h. 538.

13Lihat, misalnya, CD Rom al-Qāmūs, Versi 2, Sakhr Software, 1995/1996. Dalam kamus ini, kata haniff memiliki banyak arti, seperti straight, right, correct, proper, dan true. Arti-arti tersebut tidak ada yang menunjukkan makna "lentur" bahkan lebih menguatkan pendapat yang populer, $\underline{h}$ anif berarti lurus; Al-Qur'an dan Terjemahannya susunan DEPAG RI juga mengartikan kata hanïf dengan lurus. Lihat misalnya ketika mengartikan kata ini yang terdapat dalam ayat Ali 'Imrān: 67. Al-Qur'an dan Terjemahannya, Depag RI, h. 86.
}

${ }^{14}$ Shahrūr, al-Kitāb wa 'l-Qur'ān, h. 448. 
itu, ia memahami bahwa semua yang selain Allah adalah hanīf, berubah. Menganggap statis atas apa yang selain Allah adalah perbuatan syirik. Oleh karena itu, kata haniff disusul dengan "Ia bukan dari golongan orang yang musyrik" dalam Ali 'Imrān: 67. Percaya dengan keberubahan (ke-hanifiyyah-an) alam, percaya dengan ḥudūd yang ada di alam, dan percaya dengan pergerakan dalam batas-batas ḥudūd tersebut, merupakan tauhid rubūbiyyah. Dari sini, maka Ibrahim disebut dengan ummah qānitan lillāh haniffan (seorang imam yang dapat dijadikan teladan lagi patuh kepada Allah dan ḥaniff) (QS. al-Nahl: 120).15

Jika fenomena alam yang haniff diletakkan dalam kerangka aktivitas perbuatan manusia, maka kita akan melihat bahwa perbuatan manusia berada pada cakupan batas-batas ( $h u d u \bar{d})$ seperti yang telah ditentukan oleh Allah. ${ }^{16}$ Agama yang haniff akan sesuai dengan aktivitas perbuatan manusia, cocok dengan mereka, dan tumbuh bersama mereka. Agama yang demikian itu, adalah agama yang dibangun di atas batasan-batasan (hudūd) dalam hukum, bukan atas dasar hukum yang rinci (tashrï' 'aynī). ${ }^{17}$ Konsep ke- ḥudūd -an Islam ini, kemudian dibakukan oleh Shahrūr dalam aspek hukum. ${ }^{18}$ Yahudi dan Nasrani tidak memiliki karakteristik sebagai agama yang haniff ini, karena haniffiyyah berpindah dari Ibrahim kepada Muhammad, dari yang semula berbentuk teoretis menjadi sebuah kenyataan sebagai agama internasional yang universal, berdasarkan firman Allah "Ibrahim bukanlah Yahudi juga bukan Nasrani, tapi dia adalah seorang yang haniff dan Muslim." (Ali 'Imrān: 67). Surat al-Baqarah 71-67 merupakan bukti nyata bahwa agama Yahudi dan Nasrani merupakan agama yang tidak mengandung konsep universal-limitatif (shumūlī-hudūdī) ini, tapi agama 'aynī (konkret). Maka dari itu, Allah ketika memerintahkan kepada Bani Israil untuk menyembelih kambing, kaum Bani Israil meminta-Nya untuk memerincinya. Demikian juga ketika Allah berbicara tentang hukuman-hukuman jiwa dengan jiwa dan mata dengan mata, seperti terlihat dalam QS. al-Mā'idah: 45.19

Al-Shawāf mengkritik Shahrūr atas penggunaan kata hanîf dalam lapangan hukum Islam. Alasan al-Shawāf, kata hanīf dalam semua ayat al-Qur'an tidak ada

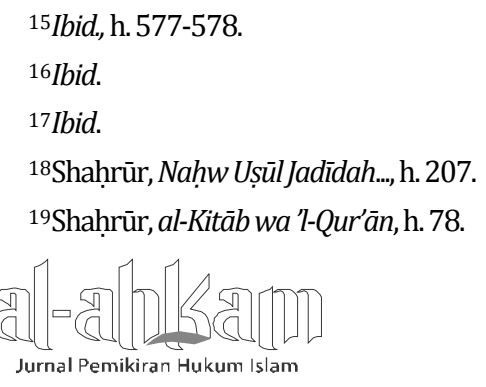


yang merujuk pada bidang hukum tapi pada bidang akidah. ${ }^{20}$ Namun, sekali lagi kritik al-Shawāf ini berangkat dari paradigma lama, bukan berangkat dari paradigma Shahrūr yang ingin membaca al-Qur'an dengan mata kepala manusia zaman ini dan mengabaikan hasil dan cara pembacaan manusia zaman dulu.

Berangkat dari konsep ḥanīf-ḥudūdī itu, Shaḥrūr berkeyakinan bahwa Islam adalah agama jalan tengah. Islam adalah agama yang pada saat yang sama menggabungkan aspek liberal dan konservatif (muhāfiz). Aspek konservatifnya terletak pada adanya prinsip-prinsip baku yang tidak boleh diganggu gugat, seperti tauhid, konsep hari akhir, dan konsep amal saleh. Sementara aspek-aspek liberalnya terlihat pada: 1) Pengakuannya atas adat-istiadat seluruh masyarakat bumi, selama tidak melampaui hudūd Allah; 2) Pengakuannya atas kebebasan, kemuliaan, dan persamaan derajat sesama manusia yang dipandang sebagai karunia Ilahi yang paling hakiki; 3) Hukum Islam yang berkaitan dengan pernikahan, talak, waris, dan hukum keluarga, merupakan hukum sipil (madani) dalam arti dibuat oleh manusia - yang mengindahkan ḥudūd Allah dan pada saat yang sama mengikuti tingkat perkembangan masyarakat, serta memanfaatkan bukti-bukti ilmiah dan voting; 4) Pakaian wanita dan laki-laki mengikuti adat kebiasaan masyarakat dalam cakupan hudūd Allah. ${ }^{21}$

Hubungan dialektis antara hanīf-ḥudūdī yang merepresentasikan dialektika antara aspek liberal dan aspek konservatif dalam Islam merupakan tonggak penting pemikiran Shaḥrūr. Shahrūr berkeyakinan bahwa dialektika ini akan mampu menunjukkan pada kita bahwa risālah Muhammad memang benar-benar cocok untuk semua waktu dan kondisi dan menunjukkan keunggulan syariat Muhammad. $^{22}$

Pada akhirnya, harus diakui bahwa Shaḥūr telah meletakkan tonggak paradigma baru dalam memahami Islam. Dalam paradigmanya itu, Islam adalah agama yang benar-benar raḥmatan li 'l-älaminn. Ia bukan agama yang sektarian, tapi agama internasional dan universal. Paradigma barunya itu, jelas akan

\footnotetext{
${ }^{20}$ al-Shawāf, Tahāfut, h. 536, 540.

21Shahrūr, Dirāsah Islāmiyah Mu'āṣirah fi' l-Dawlah wa 'l-Mujtama'(Damaskus: al-Ahālī li '-Tibā'ah wa'l-Nașr wa'l-Tawzi', 1994), h. 198.

22Māhir Munajjid, "al-Ishkāliyyah al-Manhājiyyah fi 'l-Kitāb wa 'l-Qur'ān: Dirāsah Naqdiyyah", dalam 'Ālam al-Fikr (Damaskus/Beirut: Dār al-Fikr, 1994), h. 152.
} 
membawa implikasi yang besar pada konsep-konsep hukum dan teori-teori hukum. Pertanyaannya adalah bagaimanakah paradigma baru itu dimanifestasikan dalam kerangka teoretik baru sehingga dapat melahirkan hukum Islam yang modern. Pertanyaan ini telah menantang Shahrūr untuk merekonstruksi ilmu usul fikih, sebuah ilmu yang sangat menentukan hidup dan matinya hukum Islam. Dalam Naḥw Ușūl Jadīdah, Shaḥūr menulis:

"Peradaban kita yang terbentang ini telah meninggalkan kita hal yang tercabikcabik... yang kita jumpai sebagai arena pengkafiran, pengutukan, dan penuduhan busuk apabila terlintas di benak kita untuk berijtihad dan kita mengatakan sesuatu yang belum pernah dikatakan orang-orang terdahulu atau kita mengungkapkan perkataan asing selain kesepakatan fuqahä' yang otoritatif atau menawarkan kritik pada usul fikih dan usul tafsir. Sesungguhnya kita memiliki kebutuhan yang mendesak untuk membuka kembali disket-disket ushūl dan memulai untuk merekontruksi ulang, sebagai ganti dari kita bernaung pada hal yang sudah tercabik-cabik (itu,--penulis)..."23

Shahrūr telah melakukan rekonstruksi total atas sendi-sendi dasar ilmu usul fikih tradisional. Bagaimana bentuk rekonstruksi yang ditawarkan Shahrūr itu? Tulisan ini tidak mungkin mendiskusikan semua bagian rekonstruksi usul fikih Shahrūr. Apalagi rekonstruksi Shahrūr mencakup empat bagian pokok usul fikih buatan al-Ghazālī,24 yakni hukum (al-thamrah), sumber hukum (al-muthmirah), cara menemukan hukum atau ijtihad (țuruq al-istithmār), dan mujtahid (almustathmir). Demi kedalaman pembahasan, tulisan ini hanya akan mendiskusikan paradigma baru Shahrūr tentang hukum Islam.

\section{Paradigma Baru Hukum Islam}

Shaḥrūr berpandangan bahwa Islam sebagai agama terdiri dari tiga aspek, yakni aspek akhlak (prinsip moral, teladan luhur), aspek ritual, dan aspek hukum. Dari tiga aspek tersebut semuanya menyatu dengan negara kecuali aspek ritual. Shahrūr menulis:

"Sesungguhnya agama...memiliki tiga aspek: teladan luhur yang tidak mungkin dipisahkan dari negara dan masyarakat, aspek ritual-ritual yang dipisahkan

oleh rasul yang mulia dari negara sejak masa kenabian, dan aspek tasyri' dan

\footnotetext{
${ }^{23}$ Shahrūr, Naḥw Ușūl Jadīdah..., h. 65.

${ }^{24}$ al-Ghazālī, al-Mustasfā min 'Ilm Ușūl, Jilid 1, (t.t.p.: Dār al-Fikr, t.th.), h. 7-8.$$
\text { 口 }
$$ 
Muhyar Fanani

hukum yang menggambarkan batasan-batasan (hudūd) Allah dalam kehidupan individu, negara dan masyarakat."25

Dalam bagian ini, penulis hanya akan membicarakan satu aspek saja dari ketiga aspek di atas, yakni aspek hukum.

Berangkat dari postulat bahwa Islam adalah agama internasional dan universal, Shahrūr membuat definisi baru yang orisinal mengenai hukum Islam. Baginya, hukum Islam adalah hukum sipil (hukum madani) yang manusiawi, penuh keragaman, dan berada dalam cakupan batas-batas (hudūd) Allah atau dibangun di atas hudūd Allah. ${ }^{26}$ Sebagian dari hukum ini mungkin berdiri di atas batas-batas itu, sementara mayoritasnya berada dalam cakupannya. ${ }^{27}$ Dengan demikian, Shahrūr berbeda dengan ulama usul fikih sebelumnya, yang berpendapat bahwa pembuat hukum hanyalah Allah. ${ }^{28}$ Bagi Shahrūr pembuat hukum adalah manusia sendiri. ${ }^{29}$ Allah hanya memberi batas-batasnya saja. Sehingga, mayoritas hukum penduduk bumi sekarang dapat dikatakan hukum Islam, selama masih mengindahkan batas-batas Allah. ${ }^{30}$ Dengan kata lain, Allah telah memberi batasan mana yang halal dan mana yang haram. Sedangkan manusia termasuk Nabi Muhammad hanya dapat melakukan pembolehan pelarangan, perintah, atau pencegahan dalam wilayah halal, karena tuntutan situasi dan kondisi. ${ }^{31}$

Konsepsi baru hukum Islam tersebut berangkat dari asumsi dasar Shahrūr bahwa perkembangan Islam dalam sejarah, sejak Nuh hingga Muhammad, memainkan peran yang mendasar dalam pembentukan hati nurani manusia. Dengan hadirnya Muhammad sebagai nabi penutup, maka ilmu pengetahuan, hukum, dan kemanusiaan manusia telah matang. Shahrūr menulis:

\footnotetext{
${ }^{25}$ Shahrūr, Naḥw Ușūl Jadīdah..., h. 81.

${ }^{26}$ Shaḥrūr, "Proposal for Islamic Covenant", dalam http://wwwisim/publications/other/shahrur. html, diakses tanggal 15 Februari 2007.

${ }^{27}$ Shahrūr, al-Kitāb wa al-Qur'ān., h. 580; Shahrūr, Nahww Ușūl Jadīdah, h. 207; Syahrūr, Dirāsah Islāmiyyah Mu'āșirah., h. 108, 198, 203; Kesimpulan yang sama tentang definisi hukum Islam juga dihasilkan oleh Māhir Munajjid, al-Ishkāliyyah al-Manhajïyyah, h. 157. h. 100.

28al-Ghazālī, al-Mustașfā min 'Ilm Ușūl, editor: M. Mustaṣfā Abū al-Ilā (ttp.: Maktabah al-Jundi, t.th.),

${ }^{29}$ Shahrūr, al-Kitāb wa '-Qur'ān, h. 570.

${ }^{30}$ Ibid., h. 579, Shaḥrūr, Naḥw Ușūl Jadīdah..., h. 207-8.

31Shahrūr, Naḥw Ușūl Jadīdah..., h. 143-150.
} 
“... Risālah Muhammad adalah risalah penutup — dengan dilengkapi al-Qur'ān yang merupakan nubuwwah penutup - dimana risālah-Nya mengandung arti bahwa manusia menjauh dari kerajaan hewani. Manusia berhutang pada Allah dalam dimensi ini. Sungguh Allah telah mengirimi manusia dalam hal pengetahuan dengan nubuwwah dan dalam hal hukum dengan risālah, sehingga dengan hadirnya Muhammad, manusia mencapai tingkat kematangan pengetahuan dan hukum di mana manusia mampu untuk berpegang pada dirinya sendiri dalam memahami wujud (alam) dan dalam membuat hukum (manusia modern)."32

Dengan demikian, setelah Nabi Muhammad wafat, manusia dalam membuat hukum dapat berpegang pada akalnya, tanpa perlu lagi datangnya wahyu yang baru. ${ }^{33}$

Konsepsi baru hukum Islam Shaḩrūr juga tidak lepas dari pandangannya terhadap perbedaan antara nubuwwah dan risālah. Nubuwwah adalah kumpulan informasi pengetahuan tentang kealaman dan kesejarahan yang diwahyukan kepada nabi yang dengannya ia disebut sebagai Nabi, seperti tentang persoalan benar dan salah. Semua informasi yang hadir dalam al-Kitāb disebut nubuwwah. Sedangkan risālah adalah kumpulan tasyri' (hukum) yang datang kepada nabi sebagai tambahan terhadap informasi, pengetahuan, dan kenabian yang telah diterimanya, yang meliputi persoalan ibadah, muamalah, dan akhlak, serta halalharam. Dengan tambahan itu ia disebut sebagai rasul. Jadi, singkatnya Shahrūr beranggapan bahwa nubuwwah itu informasi dan oleh karena itu, sifatnya informatif sedang risālah adalah ketetapan hukum dan sifatnya taklïf(pembebanan). ${ }^{34}$

Perbedaan antara pandangan Shahrūr tentang nubuwwah dan risālah dengan pandangan konvensional dapat dilihat dalam skema berikut:

\footnotetext{
32Shahrūr, al-Kitāb wa '-Qur'ān, h. 579.

33Sahrūr, Naḥw Ușūl Jadīdah..., h. 53, 81; Shahrūr, Dirāsah Islāmiyyah Mu'āṣirah, h. 271.

${ }^{34}$ Shaḥrūr, Naḥw Ușūl Jadīdah., h. 53; Shaḥrūr, al-Kitāb wa '-Qur'ān, h. 54; Shaḥrūr, Dirāsah Islāmiyyah Mu'ạșirah, h. 184, 185. Tentang perbedaan antara nubuwwah dan risālah ini, Shahrūr menulis: “.... nubuwwah mengandung pembenaran dan pengingkaran. Nubuwwah berasal dari wilayah (ia ada atau tiada). Sedangkan risālah mengandung ketaatan dan pelanggaran (maksiat) dengan asumsi bahwa risālah berasal dari wilayah (aku menerima atau menolak). Dari sini, kita menjumpai bahwa Nabi Muhammad ketika berdakwah pada manusia, misalnya, "Sesungguhnya kegoncangan hari kiamat itu adalah suatu kejadian yang sangat besar (dahsyat)," (QS. al-Hajj: 1) atau, misalnya, menyampaikan, "Allah itu, tak ada Tuhan kecuali Dia yang Maha hidup dan Maha berdiri kokoh," jawaban pendengar mungkin berupa "Anda benar" atau "Anda bohong". Adapun ketika rasul menyampaikan, "Barang siapa diantara kamu sedang sakit atau sedang dalam perjalanan maka gantilah (puasamu) pada hari-hari yang lain)." Maka di sini tak ada tempat untuk membenarkan atau mengingkari dan bagi pendengar supaya menerima dan menaati atau menolak dan tidak menaati," Shaḥrūr, Naḥw Ușūl Jadìdah..., h. 59.
}

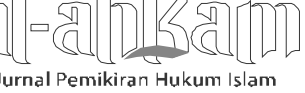

Jurnal Pemikiran Hukum Islam 
Muhyar Fanani

Pemahaman Konvensional Kenabian $=$ Kerasulan

Pemahaman Shaḥrūr

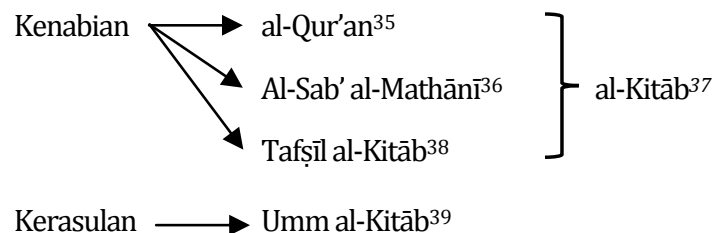

Shahrūr berpandangan bahwa risālah Muhammad terdiri dari tiga macam ajaran, yakni: ritual-ritual, akhlak, dan hukum. Ritual-ritual berupa ibadah mahḍh yang mana kita belajar pada rasul secara praktek bukan perkataan verbal. ${ }^{40}$ Akhlak adalah kode etik dan teladan luhur yang tunduk pada tahapan historis sejak Nabi Nuh hingga Muhammad, seperti berbakti pada orang tua, berbuat adil, dan menepati janji. ${ }^{41}$ Sedangkan ayat-ayat hukum merupakan lapangan hukumhukum syariat yang merupakan tempat untuk berijtihad. Bagi Shahrūr, nabi adalah seorang mujtahid yang lapangan ijtihadnya hanya terletak di wilayah ini, bukan di wilayah shi'ār ${ }^{42}$ atau akhlak.43

35Dalam terminologi Shahrūr, al-Qur'ān berarti bagian dari al-Kitāb yang berbentuk ayat mutashābihāt dan berisi petunjuk bagi seluruh manusia baik yang bertakwa maupun yang tidak bertakwa. Menurut Shahrūr, al-Qur'än merupakan sekumpulan hukum obyektif yang mengatur fenomena alam dan peristiwa kemanusiaan yang semula bukan berbentuk bahasa Arab kemudian dijadikan bahasa Arab.

36Dalam terminologi Shahrūr, Sab'al-mathānī tujuh ayat yang terpisah dari ayat lain dan menjadi pembuka tujuh surat, yakni: Aliflām mīm, Aliflām mīm șād, Kafhā yā ain șād, Yāsin, Țā hā, Țā sīn mīm,

${ }^{37}$ Dalam terminologi Shahrūr, tafșil al-kitāb adalah ayat-ayat nubuwwah yang tidak termasuk dalam kategori muhkkam dan mutashābih, tidak memiliki hubungan dengan lawh mahfüz atau imām mubīn (karena ia diwahyukan langsung dari Allah), tidak mengandung hukum dan informasi apapun selain penjelasan tentang isi al-Kitāb.

${ }^{38}$ Dalam terminologi Shahrūr, al-Kitāb dalam terminologi Shahrūr berarti semua ayat mushaf sejak dari surat al-Fātiḥah hingga surat al-Nās yang merupakan sekumpulan tema yang diwahyukan Allah kepada Nabi Muhammad, yang meliputi teks dan isinya, risālah dan nubuwwah.

${ }^{39}$ Dalam terminologi Shahrūr, umm al-Kitāb berarti bagian dari al-Kitāb yang berisi tentang persoalan ibadah, perilaku moral, dan hukum. Oleh Shahrūr, umm al-Kitāb juga disebut dengan ayat muḥkamāt atau risālah. Ayat ini sifatnya dinamis, historis, dan dipengaruhi oleh situasi dan kondisi, serta subyektif dan terkait dengan ilmu-ilmu kemasyarakatan.

40Ibid, h. 131.

${ }^{41}$ Ibid, h. 133-142.

${ }^{42}$ Shi'âr: dalam terminologi Shaḥūr berarti ajaran-ajaran tentang ibadah maḥ̣ah.

${ }^{43}$ Ibid., 143; Shahrūr, al-Kitāb wa 'l-Qur'ān, h. 452.

160 || Volume 24, Nomor 2, Oktober 2014

Jurnal Pemikiran Hukum Islam 
Konsepsi baru hukum Islam Shaḥrūr, juga sangat terkait dengan konsepsinya tentang Nabi Muhammad. Baginya, disamping sebagai nabi dan rasul, Muhammad juga seorang mujtahid yang bertugas membumikan Islam mutlak menjadi Islam nisbi pada masyarakat semenanjung jazirah Arabia pada abad ke-7 M.44 Mengingat nabi telah wafat, maka perguruan tinggi dengan forum-forum ilmiahnya menjadi pewaris nubuwwah (kenabian), sementara majelis-majelis penetapan hukum dan parlemen menjadi pewaris risālah.45 Menurut Shahrūr, saat ini adalah masa pascarisālah yang berarti pula masa pasca-pematangan hati nurani. Dengan kata lain, manusia sekarang hidup pada masa kematangan kemanusiaan, sehingga mereka bisa berpegang pada dirinya sendiri dalam membuat hukum, seperti terlihat pada pengakuan hati nurani manusia atas Hak Asasi Manusia (HAM). ${ }^{46}$

Di sisi lain, Shahrūr beranggapan bahwa kematangan kemanusiaan dan pengenalan hudūd Allah merupakan bukti atas kesempurnaan kekhalifahan manusia di atas bumi (QS. al-Māidah: 3). Manusia setiap kali mengalami kemajuan dalam peradaban, maka pemahamannya terhadap hudūd akan bertambah. Dan setiap kali jauh dari peradaban maka kejahilannya dalam hal ḥudūd akan bertambah. Shahrūr mendasarkan pandangan ini pada QS. al-Tawbah: 97.47

Shahrūr beranggapan bahwa fikih Islam yang ada selama ini belum sepenuhnya disusun dengan memanfaatkan kematangan kemanusiaan manusia. Walaupun berangkat dari teks, namun ia disusun masih berdasarkan asumsi bahwa syariat Islam adalah syariat 'aynī, bukan hudūdī. ${ }^{48}$ Pandangan Shahrūr tentang fuqahā' yang masih cenderung memandang syariat Muhammad sebagai syariat 'aynī ini, secara tidak sengaja dibuktikan oleh Khaled M. Abou el-Fadl, seorang profesor hukum di UCLA. Menurut Fadl, kecenderungan untuk lebih fokus pada perintahperintah khusus dari pada perintah yang lebih umum dan universal —dalam bahasa Shahrūr, kecenderungan untuk memandang syariat Muhammad sebagai syariat 'aynī - terlihat pada anggapan kebanyakan fuqahä' bahwa ayat-ayat alQur'an yang lebih umum di-nasakh oleh ayat-ayat yang lebih khusus. ${ }^{49}$ Disamping

\footnotetext{
44Shaḥrūr, Naḥw Ușūl Jadīdah..., h. 208, 62-3; Shahrūr, al-Kitāb wa I-Qur'ān, h. 473.

45Shahrūr, Naḥw Ușūl Jadīdah..., h. 53.

46Ibid, h. 144.

${ }^{47}$ Shahrūr, al-Kitāb wa '-Qur'ān, h. 570.

48Bandingkan dengan pemahaman Māhir Munajjid, al-Ishkāliyyah,, h. 156-7.

${ }^{49}$ Khaled M. Abou el-Fadl, Melawan "Tentara Tuhan”, terj. Kurniawan Abdullah, Jakarta: Serambi, 2003, h. 266.
}

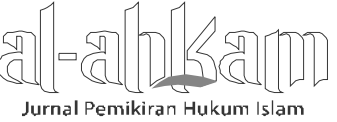


itu, kurang diperhatikannya hukum-hukum moral universal dan begitu besarnya perhatian fuqahä' pada hukum-hukum kasuistik yang bersifat spesifik ${ }^{50}$ juga merupakan bukti lain atas benarnya pandangan Shahrūr di atas.

Menurut Shahrūr, fikih Islam historis juga disusun di bawah pengaruh situasi historis masa lalu. Hiruk-pikuk politik kekuasaan antara Umayyah-Abbasiyyah di satu sisi dan Bani Hasyim-Bani Thalibiyyah pada sisi yang lain, sedikit banyak telah turut memengaruhi isi fikih historis itu. ${ }^{51}$ Sistem pengetahuan yang berjalan pada masa pembentukan fikih saat itu juga turut memengaruhi isi fikih. Fikih waris yang ada selama ini, misalnya, disusun masih berdasarkan dasar-dasar matematika klasik, belum berdasarkan matematika modern seperti geometri analitis (analytic geometry; al-handasah at-tahliliyyah), analisa matematis, dan teori himpunan, mengingat dasar-dasar geometri analitis baru ditemukan oleh Rene Descartes pada abad ke-17, sedangkan analisa matematis baru ditemukan oleh Newton pada abad ke-18, sementara teori himpunan ditemukan pada abad ke-20.52 Selain itu, fikih wanita, yang justru menomorduakan wanita juga merupakan pengaruh sistem sosial-patrilineal pada saat itu. Shahrūr tidak yakin hingga saat ini telah ada fikih wanita yang berangkat dari dialektika antara istiqāmah, hanifiyyah, dan fitrah kemanusiaan yang menjadikan batasan-batasan Allah sebagai pilar utama. ${ }^{53}$

Menurut Shahrūr, manusia sekarang membutuhkan fikih baru yang disusun berdasarkan landasan epistemologi pengetahuan yang baru dan permasalahan kehidupan yang baru. ${ }^{54}$ Pentingnya melibatkan sistem pengetahuan yang berjalan di masa sekarang sebagai landasan untuk menyusun fikih yang baru, terlihat dalam tulisan Shahrūr berikut:

"Jika ulama usul fikih telah menetapkan teori dasar "perubahan hukum karena perubahan waktu" maka kita akan menetapkan teori dan praktek dengan bantuan Allah bahwa hukum juga berubah karena perubahan sistem pengetahuan. Jika kita selesai dalam pembacaan kita yang modern pada ayat-ayat waris dalam terang cahaya matematika modern, maka tidak ada keheranan sama sekali terhadap hukum-hukum dan kesimpulan yang berbeda dari contohcontoh milik manusia abad ke-8 M. Pangkal dan akhir dari masalah itu bukanlah

\footnotetext{
${ }^{50} \mathrm{Ibid}, \mathrm{h} .161$.

${ }^{51}$ Shahrūur, Naḥw Ușūl Jadīdah..., h. 115.

52Ibid., h. 116.

${ }^{53}$ Shahrūr, al-Kitāb wa 'l-Qur'ān, h. 592-3.

54Shahrūr, Naḥw Ușūl Jadīdah..., h. 115.
} 
persoalan kepandaian dan kebodohan dan bukan pada persoalan takwa dan tidak takwa. Akar masalahnya adalah bahwa demi kemudahan problematika yang kita hadapi dan sistem ilmu pengetahuan yang kita jadikan dasar pijak mendorong kita untuk melihat apa yang orang-orang di masa lalu belum mampu melihatnya."55

Selain itu, fakta bahwa disusunnya mazhab-mazhab fikih besar yang ada selama ini, seperti Hanafi, Syafi'i, Hanbali, Maliki, dan Ja'fari berdasarkan sistem pengetahuan yang ada saat itu, sehingga mencerminkan proses interaksi antara Islam dengan lokalitas historis tertentu yang dialami fuqahä' dengan berbagai faktor-faktor politik, ekonomi, dan sosial saat itu, juga menambah semangat Shahrūr untuk mendorong munculnya fikih baru. Shaḥrūr beranggapan bahwa fikih mereka sangat cocok untuk masanya, namun belum tentu cocok untuk masa sekarang. ${ }^{56}$ Manusia sekarang tidak bisa lagi menggunakan fikih historis tersebut, apabila mereka ingin melihat Islam yang cocok untuk semua tempat dan waktu. Dalam magnum opus-nya, Shaḥūur menulis:

“... proposal yang menyerukan penerapan hukum-hukum syariah Islam berdasarkan prinsip bahwa Islam adalah apa yang diwarisi dari kitab-kitab fikih dan berdasarkan asas bahwa hudūd Allah adalah tasyri' yang konkrit (spesifik) merupakan usulan dalam kekosongan dan ilusi yang tidak mungkin berhasil. Selain itu, hal itu merupakan perbuatan yang membuang waktu, harta, dan jiwa saja. Sebagaimana diketahui, dalam konsep fikih yang diwarisi itu negara mulai dipisahkan dari agama, walaupun tidak semuanya.... Kehidupan modern memberikan kesan pada kita bahwa Islam itu tidak cocok untuk setiap waktu dan tempat. Ini tidaklah benar. Islam, dengan konsep hakiki yang kami ajukan, cocok untuk setiap waktu dan tempat."57

Dalam kutipan di atas, Shahrūr menyatakan dua poin penting yang dimiliki oleh fikih Islam historis, sehingga memunculkan krisis yang berkepanjangan hingga sekarang. Pertama, fikih historis dibentuk berdasarkan asumsi bahwa hudūd Allah adalah tasyri' 'aynī, konkret, dan spesifik. Oleh karena itu, kreativitas manusia dalam bidang hukum diperkecil. Kedua, negara dipisahkan dari agama. Akibatnya, fikih tidak pernah efektif sebagai hukum negara yang mampu mengatur warga negara secara luas.

Bagi Shahrūr, pada dasarnya syariat Islam bukanlah syariat 'aynī, tapi merupakan syariat ḥudūdī, yang membuka selebar-lebarnya bagi kreativitas manusia di

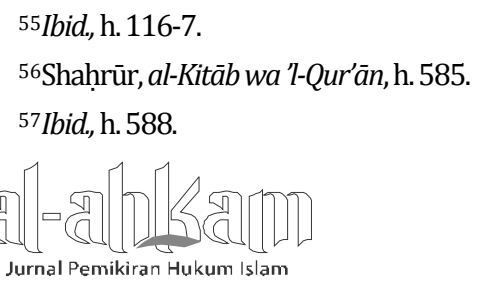


bidang hukum..$^{58}$ Oleh karena itu, ia seharusnya mampu tumbuh sesuai dengan kecenderungan manusia dan tingkat perkembangan historis, sosiologis, ekonomi, dan politik. Dengan kata lain, ia juga memiliki sifat yang haniff (fleksibel) seperti Islam itu sendiri.59 Krisis fikih yang amat parah sehingga muncul fenomena irelevansi yang akut selama ini, oleh Shahrūr dipandang lebih disebabkan oleh kesalahan metodologis ini, bukan karena kelemahan bahasa Arab apalagi tipisnya ketakwaan pencetusnya, ${ }^{60}$ sehingga watak hukum Islam yang haniff menghilang. Menurut Shahrūr, dinafikannya watak hanīf ini merupakan konsekuensi logis dari mendominasinya anggapan bahwa syariat Muhammad adalah syariat 'aynī seperti halnya syariat Musa, bukan sebagai syariat yang hudūdī (limitatif). ${ }^{61}$

Anggapan bahwa syariat Muhammad adalah syariat 'aynī juga menimbulkan kesalahan metodologis lebih lanjut, seperti munculnya kaidah yang menyatakan bahwa tidak ada ijtihad dalam teks atau tidak ada ijtihad dalam umm al-Kitāb $b^{62}$ (ayat-ayat muhkamāt). Kaidah ini menunjukkan bahwa selama ini fuqahā' telah berdiri di atas batas, bukan dalam cakupan batas. Padahal, apabila kita bermain bola, maka kita harus bermain dalam cakupan batas lapangan, bukan pada batas lapangannya. Kesalahan metodologis ini sangat terlihat pada fikih waris historis. Fuqahā' hanya berhenti di atas ayat persis, berdiri di atas batas-batasnya, dan selamanya tidak bergerak dalam cakupan batas-batas itu. ${ }^{63}$

Meyakini syariat Muhammad sebagai syariat ḥudūdī bukan 'aynī, Shaḥūr akhirnya dapat memahami mengapa risālah Muhammad dinamakan dengan umm al-Kitāb, sementara risālah Musa dan Isa dinamakan dengan al-Kitāb. Menurut Shahrūr, jawabannya adalah bahwa pada risālah Muhammad dimungkinkan terjadinya penggalian hukum dalam bentuk ribuan kitab hukum dari umm al-Kitāb tersebut.64 Mayoritas hukum-hukum modern milik penduduk bumi masuk dalam

\footnotetext{
58Shaḥrūr, Naḥw Ușūl Jadīdah..., h. 21, 143, 207.

${ }^{59}$ Shaḥūr, al-Kitāb wa 'l-Qur'ān, h. 580.

60 Ibid., h. 579.

61Shaḥūr, Naḥw Ușūl Jadīdah..., h. 21, 143, 207.

${ }^{62}$ Dalam terminologi Shahrūr umm al-Kitāb berarti bagian dari al-Kitāb yang berisi tentang persoalan ibadah, perilaku moral, dan hukum. Oleh Shahrūr, umm al-Kitāb juga disebut dengan ayat muhkamāt atau risālah. Ayat ini sifatnya dinamis, historis, dan dipengaruhi oleh situasi dan kondisi, serta subyektif dan terkait dengan ilmu-ilmu kemasyarakatan.

${ }^{63}$ Shaḥūr, al-Kitāb wa 'l-Qur'ān, h. 579.

${ }^{64}$ Ibid., h. 479.
}

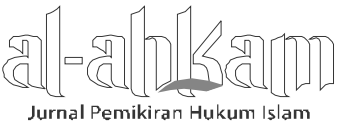


cakupan umm al-Kitāb ini, selama aktivitas penciptaan hukumnya mengindahkan batas-batas Allah.65 Manusia tidak boleh melanggar batas-batas Allah karena barang siapa melanggar batas-batas Allah maka ia berarti menzalimi dirinya sendiri.66

Meskipun tidak secara eksplisit, Shahrūr membagi hukum Islam menjadi dua bagian, hukum ibadah (maḥdah) yang oleh Shạ̣rūr sering disebut dengan shi'âr ${ }^{67}$ dan hukum muamalah. Untuk hukum ibadah (shi'ār), manusia tidak mungkin melakukan ijtihad terhadapnya. Manusia hanya menerima sebagaimana adanya dari Nabi Muhammad. Oleh karena itu, menurut Shahrūr, untuk urusan ibadah maḥ̣ah tidak ada perkembangan dan ijtihad. Nabi pun bukan mujtahid dalam persoalan ini. 68 Sedangkan untuk hukum muamalah, manusia harus meniru nabi, melakukan ijtihad agar hukum muamalah selalu berkembang dalam cakupan ḥudūd Allah. ${ }^{69}$

Termasuk dalam hukum muamalah adalah hukum pidana. Bagi Shahrūr, untuk persoalan tindak kejahatan, hukum Islam harus tegas, walaupun dalam aplikasinya lentur. Para pembuat hukum Islam harus memberikan definisi kejahatan yang dapat dituntut untuk dikenai hudūd Allah (al-ḥadd al-a'lā) dan membuat karakteristik yang jelas terhadapnya. Definisi dan karakteristik tersebut akan berbeda-beda dari tempat atau masa satu dengan yang lain. Dalam keadaan tertentu, adalah mungkin untuk mengabaikan batas atas dan cukup menjalankan hukuman yang lebih rendah. Dalam kasus pengecualian, juga mungkin untuk mempertegas hukuman maksimal dan memperluas cakupan hukuman maksimal itu. Menurut Shahrūr, inilah cara manusia sekarang mengikuti sunnah nabi dalam hal hudūd. Definisi jarimah (tindak kejahatan) tersebut harus selalu berpegang pada pendapat mayoritas masyarakat. Adalah sangat mungkin apabila dalam seribu peristiwa pencurian, hanya satu orang yang tangannya dipotong, sementara yang lain cukup dengan hukuman yang lebih ringan atau bahkan dimaafkan. Demikian pula dengan peristiwa pembunuhan. Mungkin dalam seribu peristiwa pembunuhan, yang dihukum bunuh hanya satu orang, sedangkan yang lainnya dipenjarakan atau dihukum dengan hukuman yang lebih rendah. ${ }^{70}$

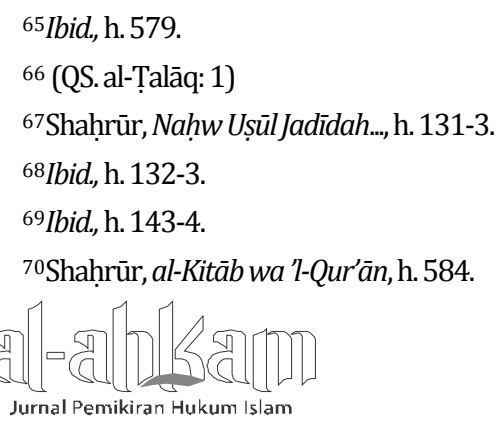


Shahrūr menambahkan bahwa dalam bidang hukum pidana, manusia harus berusaha secara sungguh-sungguh untuk tidak berdiri pada batas atas (maksimal) kecuali dalam kasus yang sudah sangat jelas terbukti dan dalam kasus pengecualian, mengingat nabi dalam pengalaman ijtihadnya pernah bersabda "hindarilah hudūd karena adanya ketidakjelasan".71 Dengan demikian, ijtihad manusia sekarang dalam hukum pidana berjalan sebagaimana ijtihad nabi.

Shahrūr berpandangan bahwa hukuman-hukuman yang telah ada selama ini, seperti hukuman bunuh, potong tangan, penjara, dan jild (cambuk) —sebagai hukuman berjenjang dari berat ke ringan- baru dijatuhkan setelah hakim mendapatkan bukti-bukti material yang akurat dan meyakinkan. Menurut Shahrūr, hukuman bunuh dan potong tangan adalah hukuman hadd ('aynî) dari Allah. Oleh karena itu, hukuman hadd baru boleh dijalankan dengan pertimbangan yang sangat matang dan bukti-bukti yang sangat meyakinkan. ${ }^{72}$ Sementara penjara, oleh Shaḥrūr dipandang sebagai hukuman yang diserahkan oleh Allah kepada para manusia untuk menentukannya. Allah tidak pernah mengatakan bahwa hukuman penjara adalah hukuman dari Allah. Hukuman penjara disebut dalam surat Yusuf sebagai hukuman dari manusia, "hukuman penguasa Mesir kepada Yusuf". Di samping itu, hukuman ini lebih berat dari hukuman jild, karena hukuman ini menghilangkan aspek kebebasan manusia yang merupakan aspek paling sakral yang dimiliki manusia. ${ }^{73}$ Apabila manusia sudah hilang kebebasannya maka ia tidak lagi bisa disebut manusia. Disamping itu, Shahrūr beranggapan bahwa penjara lebih berdampak berat dari pada jild. Karena jild tidak memisahkan manusia dari pekerjaannya, tidak berakibat pada keluarga — bagi yang mempunyai tanggung jawab keluarga-, tidak menuntut nafkah dari negara dan biaya pemeliharaannya, tidak merusak manusia dari aspek moral sebagaimana penjara, dan manusia rata-rata memilih jild dari pada penjara apabila kepadanya diajukan dua pilihan, penjara atau jild. ${ }^{74}$

Pelaksanaan hukuman terhadap para orang yang bersalah, menurut Shahrūr, harus dilakukan dengan cara terbuka dan disaksikan umum. Shahrūr beralasan,

\footnotetext{
71 Ibid., h. 580.

72Ibid, h. 591.

${ }^{73}$ Dengan mengakui bahwa kebebasan adalah aspek paling sakral dari manusia, maka tampak bahwa Shahrūr jelas banyak membaca pikiran para filosof Barat abad pencerahan. Filosof pada abad pencerahan banyak yang berpandangan demikian. Lihat: Gaarder, Dunia Sophie.., h. 360.

${ }^{74}$ Ibid., h. 591.
}

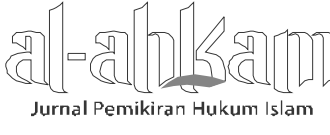


hukuman itu selain untuk memberikan pendidikan pada masyarakat agar tidak melakukan kejahatan serupa juga untuk —bahkan ini menurut Shaḥrūr jauh lebih penting - menunjukkan aspek tanggung jawab dari para pemegang kekuasaan dan para hakim dalam memberikan hukuman dengan hukuman terbuka itu. Maka asas akuntabilitas publik dalam menjalankan hukum dapat ditegakkan. Dengan demikian, asas demokrasi dalam pemberian hukuman dapat diwujudkan. ${ }^{75}$

Semua paparan di atas, terlihat bahwa Shahrūr memiliki paradigma baru tentang apa yang dinamakan hukum Islam. Apabila para pakar usul fikih selama ini memandang bahwa hukum adalah titah ilahi yang berkaitan dengan perbuatan orang mukallaf, ${ }^{76}$ maka Shahrūr mendefinisikan hukum Islam sebagai hukum sipil buatan manusia yang di satu sisi mengindahkan titah ilahi, ḥudūd Allah, dan di sisi lain memperhatikan situasi dan kondisi sosial masyarakat. ${ }^{77}$ Shaḥūr ingin mengubah hukum Islam yang semula sebagai hukum langit menjadi hukum bumi yang masih mengindahkan rambu-rambu langit. Sebagai upaya pembumian hukum Islam, maka pemikiran Shahrūr dalam bidang hukum sangat jelas dipengaruhi oleh prinsip-prinsip tata dunia sekarang, seperti konstitusionalisme, ${ }^{78}$ negara-bangsa (nation-states), masyarakat madani, demokrasi, pembagian kekuasaan, dan prinsip akseptabilitas serta akuntabilitas publik. Shahrūr ingin mewadahi hukum Islam dengan wadah yang sudah diterima secara internasional yakni demokrasi. Ia menyadari bahwa demokrasi adalah bentuk teknis paling mutakhir dan paling sah menurut dunia internasional dari prinsip musyawarah (shūrā) yang dianjurkan oleh al-Qur'an.79 Siapapun yang ingin melaksanakan prinsip syūrā, ia harus

\footnotetext{
${ }^{75}$ Ibid, h. 592.

76Khallāf,' 'Ilmu Ushūl al-Fiqh,, h. 100.

77Shahrūr, Naḥw Ușūl Jadīdah..., h. 151.

${ }^{78}$ Konstitusionalisme merupakan pandangan bahwa kehidupan berbangsa dan bernegara diatur berdasarkan konstitusi. Konstitusi itu sendiri dapat dikatakan sebagai suatu kerangka kerja bagi kehidupan publik suatu negara yang akan memberikan arah dan ketentuan bagi jalannya negara. Pada abad ke-20, kemenangan pandangan ini hampir lengkap. Semua negara di dunia memiliki konstitusi tertulis. Richard S. Kay, "American Constitutionalism", dalam Larry Alexander (ed.), Constitusionalism: Philosophical Foundations, Cambridge: Cambridge University Press, 1998, h. 16; Joseph Raz, "On the Authority and Interpretation of Constitutions: Some Preliminaries", dalam Larry Alexander (ed.), Constitusionalism: Philosophical Foundations., h. 175.
}

${ }^{79}$ Sejarah telah membuktikan bahwa demokrasi yang walaupun semula hanya ide lokal masyarakat Barat (Eropa Barat dan Amerika Utara) dimana struktur-struktur feodal runtuh dan digantikan oleh cita-cita pencerahan budi, rasionalisme, individualisme, sekularisasi, kebabasan, kesamaan, dan persaudaraan, namun demokrasi telah tumbuh menjadi sistem politik yang tak lekang oleh panas dan tak lapuk oleh hujan. Bahkan di abad ke-21 inipun, semakin diyakini bahwa

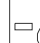

Jurnal Pemikiran Hukum Islam 
menjalankan demokrasi. ${ }^{80}$ Bahkan menurut Shahrūr, prinsip-prinsip demokrasi seperti kebebasan berpendapat, merupakan syarat mutlak untuk mewujudkan masyarakatyang sehat. 81

Di satu sisi, Shahrūr ingin bersikap realistis terhadap tata politik hukum dunia modern, tapi di sisi lain, ia ingin tetap setia dengan panduan wahyu. Solusi yang ia tempuh dengan menjadikan hukum Islam sebagai hukum yang diproduksi secara legal oleh struktur dan kelembagaan politik modern, merupakan solusi cerdas. Solusi ini ia pilih berdasarkan realitas-sosial-historis kontemporer, yang mana hampir seluruh negara modern memandang parlemen —atau apapun namanyasebagai lembaga perwakilan rakyat yang sah.

Solusi itu juga ditempuh Shahrūr karena ia memiliki keyakinan yang kuat bahwa hukum dan negara adalah satu-kesatuan yang tak terpisahkan.82 Bagi Shahrūr, yang disebut negara/masyarakat Islam adalah negara madani yang mengindahkan hudūd Allah dan menaati al-muthul al-'ulyā83 yang ada dalam alTanzīl. ${ }^{84}$ Bentuk negara-bangsa yang sudah sangat umum diterima di seluruh dunia seperti sekarang ini, sangat disadari oleh Shahrūr. Shahrūr beranggapan bahwa selama masyarakat internasional menerima bentuk negara-bangsa, maka hukum Islam harus menyatu dengan sistem negara-bangsa. Inilah letak fleksibilitas hukum Islam. Ia adalah hukum sipil yang lentur dan selalu menyesuaikan diri dengan tingkat perkembangan masyarakat dunia.

Solusi itu juga diyakini Shaḥrūr sebagai jalan terbaik untuk menjadikan hukum Islam sebagai hukum yang demokratis. Oleh karena itu, Shaḥūr dalam banyak tempat di bukunya sering mengungkapkan bahwa hukum Islam sebagai hukum sipil (hukum madani) yang mengindahkan ḥudūd Allah, harus diproduksi secara

demokrasi adalah satu-satunya sistem pencapaian kekuasaan yang sah dan manusiawi. Apabila ada negara di abad ini yang tidak menjalankan prinsip-prinsip demokrasi, maka ia pantas dianggap sebagai musuh peradaban modern. Amy Gutmann, "Democracy", dalam Robert E. Goodin dan Philip Pettit (ed.), A Companion to Contemporary Political Philosophy (Cambridge, Massachusetts: Blackwell Publishers Ltd. 1995), h. 411.

80Shahrūr, Naḥw Ușūl Jadīdah..., h. 210.

81 Ibid., h. 207.

${ }^{82}$ Shahrūr, al-Kitāb wa'l-Qur'ān, h. 588; Shahrūr, Naḥw UșūlJadīdah..., h. 81 Islam.

${ }^{83} \mathrm{al}-$ Muthul al-Ulyā secara bahasa berarti teladan luhur. Dalam terminologi Shahrūr berarti rukun 84Shahrūr, Naḥw Ușūl Jadīdah..., h. 207, 155. 
demokratis. Artinya ia harus diproduksi oleh lembaga demokrasi dan melalui cara yang demokratis pula. Oleh karena itu, voting (al-tașwit) dan polling (al-istiftā') di parlemen merupakan cara yang tak terhindarkan dalam memproduksi hukum Islam modern.85 Bahkan Shậuūr beranggapan bahwa semua negara di dunia ini dapat dikatakan mengikuti sunnah nabi, apabila negara itu memiliki parlemen, melakukan voting, polling, dan amandemen konstitusi. Ini persis seperti yang dilakukan nabi ketika mendirikan negara Madinah dimana nabi dengan itu melakukan pembatasan atas yang absolut dan memutlakkan hal yang muqayyad (terbatas) sesuai dengan tuntutan situasi lokal-historis yang nisbi. ${ }^{86}$ Apabila suatu usulan hukum, walaupun materinya sudah sangat mencerminkan ḥudūd Allah, akan tetapi dalam suatu negara tertentu usulan tersebut ditolak oleh parlemen dari negara tersebut, maka usulan hukum tersebut harus dibatalkan dan tidak perlu diundangkan.

Pendek kata, menurut Shahrūr dalam hukum Islam modern, peran mufti dan lembaga fatwa telah digantikan oleh lembaga perwakilan (DPR-MPR). Untuk itu, kebebasan berpendapat dan prinsip demokrasi harus dijunjung tinggi. ${ }^{87}$ Hukum pun harus diproduksi secara demokratis dan dilakukan oleh lembaga demokrasi.

\section{Kesimpulan}

Kontribusi Shahrūr untuk menjadikan hukum Islam sebagai hukum sipil (hukum Madani) menelurkan konsep-konsep kunci, seperti teori ḥudūd, paradigma baru pemahaman al-Qur'an, definisi baru sunnah nabi, definisi baru qiyas, dan definisi baru ijma'.

Ikhtiar Shahrūr untuk menjadikan hukum Islam sebagai hukum sipil (hukum Madani) telah memberi kontribusi riil berupa redefinisi konsep-konsep kunci, seperti teori hudūd, paradigma baru pemahaman al-Qur'an, pemahaman baru sunnah nabi, qiyas, dan ijma'. Redefinisi dan rekonstruksi inilah yang diharapkan mampu membawa perubahan arah hukum Islam dari yang semula selalu berorientasi pada teks suci — sebagai manifestasi dari teosentrisme - menjadi berorientasi pada antroposentrisme melalui kreativitas akal manusia. Penalaran semacam inilah sesungguhnya yang dilakukan 'Umar ibn Khațāab, ketika ia tidak

\footnotetext{
85Ibid., h. 208.

86Ibid., h. 155.

${ }^{87}$ Ibid., h. 208.

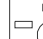

Jurnal Pemikiran Hukum Islam
} 
mau memberikan bagian zakat kepada para muallaf, tidak memotong tangan para pencuri, dan mengembalikan tanah di daerah penaklukan kepada para pemilik semula.

Pemikiran hukum Shạ̣rūr memiliki kemiripan dengan pandangan reformis hukum Islam lain, misalnya Muhammad al-Nuwayhī yang menghendaki untuk dibukanya peran manusia dalam menciptakan hukum. Keduanya sepakat bahwa hukum harus menyentuh realitas masyarakat. Untuk itu, peran manusia harus diperlebar untuk memperluas peluang antroposentrisme hukum Islam. Namun demikian harus diakui bahwa struktur kemasukakalan Shahrūr dalam bidang hukum memang benar-benar baru dan mencerminkan paradigma yang sama sekali baru. Walaupun benih-benih ke arah paradigma ini pernah muncul pada masa-masa sebelumnya, kehadiran pemikiran Shahrūr semakin memperkokoh tuntutan untuk dipergunakannya paradigma baru dalam hukum Islam sehingga lebih demokratis. [a]

\section{DAFTAR PUSTAKA}

Fanani, Muhyar, "Bagaimana Mendefinisikan Ulang Sumber Hukum Islam? Sebuah Tawaran Muhammad Shahrūr ", dalam International Journal Ihya' 'Ulum alDin Volume 9. Number 1, June 2007.

Fanani, Muhyar, "Muhammad Shahrūr dan Konsepsi Baru Sunah", dalam Jurnal Teologia, Vol. 15, No. 2, Juli 2004.

al-Ghalayaynī, Muștafā, Jāmi' al-Durūs al-'Arabiyyah, Beirut: Manshūrāt alMaktabah al-'Așriyyah, 1987.

al-Ghazālī, al-Mustașfā min 'Ilm Ușūl, ttp: Dār al-Fikr, t.th.

Gutmann, Amy, "Democracy", dalam Robert E. Goodin dan Philip Pettit (ed.), $A$ Companion to Contemporary Political Philosophy, Cambridge, Massachusetts: Blackwell Publishers Ltd. 1995.

al-Jābirī, Agama, Negara, dan Penerapan Syari'ah, terj. Mujiburrahman, Yogyakarta: Fajar Pustaka Baru, 2001.

Khallāf, Abd al-Wahhāb, 'Ilmu Ușūl al-Fiqh .

Munajjid, Māhir, al-Isykāliyah al-Manhajiyyah fi al-Kitāb wa al-Qur'ān: Dirāsah Naqdiyyah, dalam 'Ālam al-Fikr, Damaskus/Beirut: Dār al-Fikr, 1994.

Munawwir, Ahmad Warson, al-Munawwir (ttp.: tnp., t.th.),

170 || Volume 24, Nomor 2, Oktober 2014

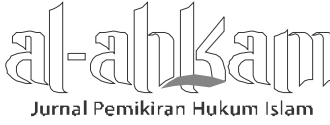


al-Qarḍāwī, Yūsuf, Fatwa-fatwa Kontemporer, terj. As'ad Yasin, Jakarta: Gema Insani Press, 1995.

Raz, Joseph, "On the Authority and Interpretation of Constitutions: Some Preliminaries", dalam Larry Alexander (ed.), Constitusionalism: Philosophical Foundations.

S. Kay, Richard, "American Constitutionalism", dalam Larry Alexander (ed.), Constitusionalism: Philosophical Foundations, Cambridge: Cambridge University Press, 1998.

al-Shawāf, Muhāmī Munīr Muhammad Thāhir, Tahāfut al-Qirā'ah al-Mu'āshirah, cet. 1, Cyprus: Asy-Syawwāf li an-Nasyr wa ad-Dirāsāt, 1993.

Shahrūr, Muhammad, Dirāsah Islāmiyyah Mu'āșirah fi ad-Dawlah wa al-Mujtama', Damaskus: al-Ahālī li ath-Thibā'ah wa 'n-Nasyr wa 't-Tawzī', 1994.

Shahrūr, Muhammad, Naḥw Ușūl Jadīdah li I-Fiqh al-Islāmī, Damaskus: al-Ahāī̄ li ath-Thibā'ah li an-Nasyr wa at-Tawzī', 2000.

al-Turābī, Hasan, Fiqh Demokratis: Dari Tradisionalisme Kolektif menuju Modernisme Populis, terj. Abdul Haris dan Zaimul Am, Bandung: Penerbit Arasy, 2003.

Wehr, Hans, A Dictionary of Modern Written Arabic, J. Milton Cowan (ed.), cet. ke-3, Beirut: Maktabah Lubanan, t.th.

Internet:

Shahrūr, Muhammad, "Proposal for Islamic Covenant", dalam http://www.isim/ publications/other/shahrur.html, diakses tanggal 15 Februari 2007. 
172 || Volume 24, Nomor 2, Oktober 2014 